\title{
Factors affecting SMEs' strategic decisions to approach international markets
}

\section{Carla Azevedo Lobo}

Research on Economics, Management and Information

Technologies (REMIT),

Instituto Jurídico Portucalense (IJP),

Universidade Portucalense,

Porto, Portugal

Email: cadsa@upt.pt

\section{Cristina I.M.A.S. Fernandes* and João J.M. Ferreira}

Department of Business and Economics,

University of Beira Interior,

Estrada do Sineiro, 6200-209 Covilhã, Portugal

and

NECE Research Unit in Business Sciences,

Covilhã, Portugal

Email: cristina.isabel.fernandes@ubi.pt

Email: jjmf@ubi.pt

*Corresponding author

\section{Marta Peris-Ortiz}

Universitat Politècnica de València,

València, Spain

Email: mperis@doe.upv.es

\begin{abstract}
The internationalisation challenges that face all companies are no longer the exclusive concern of multinationals. Participation in the international marketplace has become a reality for large firms and small and medium-sized enterprises (SME) alike. This kind of participation can be rewarding for both companies and employees. The markets that SMEs enter and the success of this entry depend on several factors such as cultural differences, company tradition, venture capital, products and competitors. The goal of this study is therefore to understand whether the characteristics of the external market, the characteristics of the company itself and the barriers to internationalisation influence the strategic approach that SMEs adopt in their internationalisation processes. Using data on 320 Portuguese SMEs, we apply multivariate analyses to test the dimensions of internationalisation. We find that the decision of SMEs to internationalise involves an institutional change in response to external pressures in the home country. SMEs under greater institutional pressure not only tend to expand further but also engage in their initial international activities more radically.
\end{abstract}

Keywords: internationalisation; SMEs; strategic approach; external market; barriers. 
Reference to this paper should be made as follows: Lobo, C.A., Fernandes, C.I.M.A.S., Ferreira, J.J.M. and Peris-Ortiz, M. (2020) 'Factors affecting SMEs' strategic decisions to approach international markets', European J. International Management, Vol. 14, No. 4, pp.617-639.

Biographical notes: Carla Azevedo Lobo ( $\mathrm{PhD}$ in Management) is Assistant Professor at the Portucalense University, Oporto, Portugal. She is researcher member at REMIT - Research on Economics, Management and Information Technologies. Her research interests are internationalisation and entrepreneurship. She is the leading researcher of a project on internationalisation financed by Portuguese and European funds (IEcPBI). She is reviewer of some international journals, and she has published in several international journals.

Cristina I.M.A.S. Fernandes ( $\mathrm{PhD}$ in Management) is Assistant Professor at the University of Beira Interior (UBI), Portugal. She is researcher member at NECE, Research Centre in Business Sciences, University of Beira Interior (UBI). Her research interests are knowledge intensive business services, innovation, competitiveness and entrepreneurship. She is editor and in reviewer board of some international journals, author of some books and she has published extensively in a variety of leading journals.

João J.M. Ferreira ( $\mathrm{PhD}$ in Management) is Associate Professor at the University of Beira Interior (UBI), Portugal. He is Scientific Coordinator of NECE - Research Centre in Business Sciences. His research interests include strategy, competitiveness and entrepreneurship. He is editor and in reviewer board of some international journals, author of some books and he has published extensively in a variety of leading journals.

Marta Peris-Ortiz (PhD in Management) is an Assistant Professor in the Polytechnic University of Valencia. She received her $\mathrm{PhD}$ in Management from the University of Valencia. Her current research is focused on the topics of entrepreneurship, human management resources and organisational design. She has published articles in various international journals.

\section{Introduction}

With the increasing international liberalisation of commercial and industrial activities, the internationalisation of business concerns both large and small companies. It is no longer restricted to the most daring companies or those devoted to operating abroad.

Types of internationalisation have also changed. Internationalisation no longer refers solely to the traditional practices of exporting to a distant customer or opening a subsidiary abroad to exploit the comparative advantages of a foreign country. Internationalisation now covers a huge variety of forms, including intra-company trade, cross-investment between companies from different countries and, above all, various types of cooperation agreements involving firms of different sizes, financial companies, governments, supranational institutions and so forth. Internationalisation by a certain company may even be initiated not by the export of goods or services but rather by the creation of a productive unit abroad or a company that is simply already global. Such companies are known as born globals (Gibb and Szałucka, 2012).

To explain some of the changes that have occurred in recent decades, Ahsan and Wyk (2018) point out that three important changes have had repercussions on firms' 
internationalisation strategies. The first is the role played by small and medium-sized enterprises (SMEs), which, through a wide variety of methods, have extended their reach across borders, showing that external activity is not the exclusive pursuit of multinationals. The second is the proliferation of new institutional formulas to access international markets. The predominance of the parent-subsidiary company relationship that was so characteristic of the 1960 s has ended, yielding to more flexible contractual formulas that allow better use of competitive advantages, even in changing contexts. The third change is that internationalisation has ceased to be a solitary venture. It now occurs within a network of interfirm agreements.

In parallel, the global economic environment has changed dramatically (Dana and Wright, 2004). Traditionally, competition in international markets was the realm of large enterprises, whilst smaller firms operated at a local or regional level. However, removing barriers to entry imposed by governments and protective domestic markets, coupled with recent technological advances in industry, transport and telecommunications, has enabled even smaller companies to access customers, suppliers and employees around the world. The evolution of information and communication technology has also had a positive effect in this new era of internationalisation (Dutot et al., 2014). Small entrepreneurial firms increasingly stimulate economic growth and innovation both domestically and internationally.

The changes in the international business environment have complicated foreign market selection. These changes, which involve the formation of regional trade groupings, the creation of strategic alliances between companies and the relentless spread of information technology, have brought down barriers between countries (Basle et al., 2018; Ferreira et al., 2018; Kraus et al., 2018). Thus, the internationalisation horizons of SMEs must be viewed from a strategic perspective.

For all these reasons, a key aspect of a company's international strategy has become the choice of the foreign market approach strategy. These changes, as well as their impact on the internationalisation strategies of companies, especially SMEs, justify the need to study internationalisation and the challenges companies face to enter new markets.

All these aspects of internationalisation reflect a growing concern to address the issue from a strategic management perspective (Autio, 2017; Magnani et al., 2018) and a behavioural orientation rather than simply portraying the economic view. We base our theoretical conceptualisation on these two approaches to study the relationships between the intrinsic characteristics of the company (Magnani et al., 2018), the external environment (Dess et al., 2008) and the full range of strategic approaches to entering the international market. Most research has studied the internationalisation of large companies. Few studies have examined this process in the context of SMEs. Despite the wealth of internationalisation studies, few have focused on the SMEs' strategic approaches to internationalisation.

At European Union (EU) level, micro and SMEs constitute 99\% of enterprises in the EU. They are an essential part of the non-financial business sector and account for two out of three jobs in the private sector contributing more than half of the total added value created by enterprises.

As suggest by some authors (Raoul et al., 2015; Braga et al., 2018; Forte and Moreira, 2018), the internationalisation is a necessary strategy for a firm's growth and survival particularly for SMEs operating in small or saturated markets, as is the case in Portugal where the exports played a very important role as the engine of economy growth especially given the recent period of economic recession. Given that SMEs dominate European industry, in particular for Southern European countries that have some 
similarities it is very important to examine the factors affecting the SEM strategic decisions in order to devise adequate policies to promote SMEs internationalisation.

More specifically, there is a lack of research on the role of the characteristics of the company's external environment, which can be considered either facilitators or inhibitors of internationalisation.

Therefore, our main research question is as follows: What specific company factors, external factors and inhibiting factors affect the strategic decisions of SMEs to approach external markets? This study provides several contributions. First, although previous literature sheds light on the internationalisation of large firms, this study makes a novel contribution by showing the strategic dimensions, particularly the characteristics of the external market, firm internal factors and inhibitors, affect SMEs. Second, this study extends our knowledge of internationalisation, especially in the SME context. SMEs face specific challenges such as a lack of human, financial, technological and informational resources. SMEs strategically opt to form cooperative alliances with companies that provide them with faster access to new markets.

Furthermore, SMEs are highly sensitive to their external environments and respond to the institutional pressures of the home country by moving aggressively to internationalise. Company size, type of ownership, type of activity, availability of external financing, availability of business associations and market share are other variables that may affect SMEs' internationalisation processes.

This paper is organised as follows. In Section 2, we review the literature on internationalisation. More specifically, we explore internationalisation factors, inhibitors and the strategic approach to the external market. Section 3 introduces the method. The empirical results and discussion are presented in Section 4. Finally, conclusions are provided in Section 5.

\section{Strategic approach to internationalisation: theoretical background}

Business internationalisation in macroeconomic terms is related to the flows of exchanges of raw materials, finished and semi-finished products, services, money, ideas and people between two states or nations. Seeking to enter the global market has become imperative, not only in terms of survival but also as one of several growth strategies. In the face of economic globalisation, internationalisation has become a crucial strategy for companies that want to empower their growth (Luo et al., 2005; Sapienza et al., 2006). Barber and Darder (2004) portray internationalisation as a process of strategic management whereby firms assess the changing conditions of the international environment and, based on their resources, develop a suitable organisational response that involves crossing international borders. Fernández and Nieto (2005) argue that internationalisation is the most complex strategy a company can undertake, given its uncertainty, its risk and the need for teams with cross-cultural competencies and cultural intelligence.

Czinkota et al. (1999) provide a list of key factors that influence the strategic approach to business internationalisation. These factors are grouped into proactive factors (potential advantages in terms of profits, technology, unique products, information management, tax benefits and economies of scale) and reactive factors (competitive pressure, excess capacity, saturation of the domestic market and proximity to customers).

Pedersen et al. (2002), Puck et al. (2009) and Benito et al. (2009) offer a proposal that resembles Czinkota et al.'s (1999) but is more comprehensive and complementary. They 
propose two types of factors (reactive and mixed) that influence strategic management of internationalisation. Reactive motivations include internationalisation by entrainment and the imperatives of the business itself. Mixed motivations include, for example, geographic proximity and cultural and linguistic affinities, the use of economies of scale to take advantage of the country's image, and support from the home or host government.

For Nigh (1985) and Sethi et al. (2003) the most important motivations for internationalisation are market characteristics in terms of either the limitations of the domestic market or the perceived dynamism of external markets. Mathews (2006) argues that companies might internationalise for relational motives (by responding to competitors, following up on customers' internationalisation processes or acting upon approaches of foreign companies), access to foreign resources (finding lower production costs abroad or accessing technological knowledge through branches) or government incentives (through the support of the home or host government). The broader economic environment, the market conditions, the size of the internal market and the firm's proximity to external markets can also be considered external motivations for internationalisation (Dess et al., 2008).

\subsection{Inhibiting factors}

According to Douglas and Craig (1995), three types of factors that are external to the company may hinder its internationalisation strategy. The first one refers to the results of PEST (political, economic, social and technological) analysis, sector and customers (more or less uniform requirements and marketing), costs (new product development, economies of scale and transport), country-specific factors (trade policy, technical standards, institutional and cultural barriers), competitive factors of the industrial structure (competitive interdependence and competition through new entrants, shareholder pressures, mergers and alliances) and the company (bipolarisation between companies that opt for global competition or focus on a particular niche or market segment).

The second concerns regulations in importing countries and access to information on these markets, which can condition this process (Katsikeas and Pierce, 1993). The third factor is the cost of labour. This factor is crucial in decision-making. However, less restrictive legislation, particularly in relation to environmental issues and sourcing raw materials, supports the decision. Besides European Community initiatives to develop programmes to support SME internationalisation, other issues also require an internal approach to the company, such as under-trained human resources for internationalisation (Pellegrino and McNaughton, 2015).

Much of the internationalisation literature was inspired by the Uppsala School. The Uppsala internationalisation model (Johanson and Vahlne, 1977) was initially based on Swedish companies (Johanson and Wiedersheim-Paul, 1975) and a behavioural perspective. According to the model, a company's market knowledge is the driver of the internationalisation process. Market knowledge is depicted as a dimension of the psychic distance between home and host countries and the cumulative experience of the firm in each given market. Lam and White (1999) argue that the Uppsala model lacks the specification of internal problems and obstacles that managers face during the organisational change involved in internationalisation. They explore the types of management dilemmas that organisations face when they internationalise. The adaptive choice model suggests that the internationalisation process unfolds as a company adaptively resolves strategic, structural and human resource dilemmas (Pellegrino and 
McNaughton, 2015; Ahsan and Van Wyk, 2018). Based on these theoretical considerations, we formulate our first hypothesis.

H1: Inhibiting factors have a significant influence on the strategic approach to internationalisation.

\subsection{Market characteristics - choice of strategy}

Guillén and García-Canal (2009) and Rui and Yip (2008) focus on growth strategies in relation to companies' approaches to foreign market entry to grow beyond the confines of the national market. This decision might be a response to fierce competition, restrictive business expansion public policies, a lack of consumer sophistication or a host of other factors that lead companies to internationalise and exploit opportunities in new markets. Usually, these opportunities are detected by the company's business partners in a given market, or they result from poor partner performance, which leads companies to rethink their strategies (Lambe et al., 2002).

Douglas and Craig (1995) and Magnani et al. (2018) argue that certain internal company factors determine the choice of internationalisation strategy. They highlight the international vision and mentality of managers, organisational dynamics and the management of organisational change. Organisational dynamics include core competencies, market access (customer proximity), company integrity (ability to be faster, more flexible or more reliable), product functionality, the ability to adapt to new processes (learning), and organisational inheritance or crisis (Pellegrino and McNaughton, 2015). The management of change entails education and communication methods, participation and involvement, negotiation and agreements, and manipulation and coercion.

According to Katsikeas and Pierce (1993), the internal agents are the managers, and the managers of the company are the main decision-makers for matters regarding internationalisation and the identification of competitive advantages, which may include installed capacity, accumulated stock volume and new orders. According to Moghaddam et al. (2014), Dunning's (1992) model is based on four motivational factors: resource seeking, market seeking, efficiency seeking and strategic-asset seeking. Although this typology provides an important reference to explain the motivations for the international expansion of multinationals from developed countries, empirical research has verified that the motivations of smaller companies may actually be quite different.

Internationalisation is still seen by many companies as a way of reducing risk across the numerous countries where they operate. Given the role of economic cycles, internationalisation is used to offset the performance of some countries with that of others, thereby turning disadvantages into advantages. The prospect of accessing more affordable factors of production in other countries means that companies view internationalisation as a means of achieving cost reductions and economies of scale (Cuervo-Cazurra and Genc, 2008; Lockyer, 2013; Hennebel et al., 2017).

In terms of strategic objectives, Van Tulder (2015) identified three groups of motivations for internationalisation: intrinsic, extrinsic and mixed. Intrinsic motivations include the aforementioned model designed by Dunning (1992). Extrinsic motivations refer to the motivations to exit the internal market. Mixed motivations relate to the specific dynamics in each sector.

Knowing the local competition is essential to be able to act locally (Peng, 2009). Logistical issues are an important factor in internationalisation. The organisation of communication and information networks in a given market must also be considered 
when choosing the best internationalisation strategy (Baum et al., 2000). At the start of the internationalisation process, firms tend to incur higher costs than competitors in the external market. These higher costs derive from transaction costs and coordination costs. These costs relate to doing business outside the domestic market (Johanson and Vahlne, 1977), which is known as the liability of foreignness. However, as the advantages of ownership are exploited and the role of the company's strategic objectives is taken into account, the company's performance in international markets will tend to evolve without necessarily following the process of gradual internationalisation (Johanson and Vahlne, 2009; Autio, 2017).

Most internationalised SMEs face limitations in terms of resources, skills, information, financial capital, managers' experience and constraints inherent in the vulnerability of the external environment. Alliances are therefore a widely used way for SMEs to internationalise. In addition to minimising costs, sharing risks and enabling access to key resources, alliances also have major advantages in terms of networks, resources and knowledge of partners (Gulati, 1998; Pellegrino and McNaughton, 2015). Because of their vulnerability to problems such as a lack of trust in partners, conflicts of interest and cultural differences (Kogut, 1989), alliances are not necessarily synonymous with success. Above all, finding the right partner is crucial (Baum et al., 2000).

According to Peng (2009), the strategic tripod may be the best way to approach the external market. Three fundamental perspectives are considered: the industry, the company's resources and competencies, and the country's institutional environment. Another factor is also proposed. This factor is the existence of clusters of companies that sell products that add value to the industry's products (Bonardi and Durand, 2003).

Firm size is also a factor in the internationalisation process (Dess et al., 2008). In most cases, resource restrictions condition the choice of market where a company intends to expand, thereby limiting business to frontier countries. Combining the scarcity of resources with the cultural proximity that often exists between frontier countries, means that companies view these as complementary and favourable factors for internationalisation in these territories (Yamin and Sinkovics, 2006; Raposo et al., 2014).

The role of institutions in the choice of corporate internationalisation strategy has also been the subject of several studies, which have examined the role of both legislation (formal institutions) and cultural ethics and human relations (informal institutions) (Parkhe, 2003; Kotabe and Mudambi, 2003). This type of organisation reduces business uncertainty (Elbana and Child, 2007) and transaction costs, which can become prohibitive for companies.

Another strategy for the internationalisation of companies was proposed by Malhotra et al. (2009), who considered only two perspectives: the environment, or the country's surroundings, and the company's intrinsic variables. The first perspective concerns the characteristics of the market under analysis. Relevant characteristics include human capital, technology and natural resources, as well as political, cultural and government issues, although the company has no scope to influence the management of government. The second perspective concerns specific company factors such as R\&D capacity, knowhow, financial capital, technological means and managers' marketing and distribution skills.

In addition to the main trends in new forms of competition and organisation, the prevailing opinion is that there is no place for companies that decide to compete in isolation. If this opinion is true for large firms, it is even more so for small firms (Blomstermo et al., 2004). For Korsakienė and Tvaronavičienė (2012), SMEs are characterised by their flexibility, adaptability and innovation, but establishing 
relationships in international markets requires greater skills, management, knowledge and long-term availability, as well as human resources to develop an effective and consistent internationalisation strategy.

Many companies lack high-value information. The smallest companies and those taking their first steps towards internationalisation need the resources and expertise to identify business opportunities abroad, potential partners, foreign trade practices, export procedures, import regulations, standards and specifications of products, and so on.

Korsakienè and Tvaronavičienè (2012) also point out that by their very nature, networks facilitate this interaction between different companies and organisations that share common objectives and interests and represent a source of cost-effective synergies. These synergies may arise through cost sharing, better or faster access to new technologies, or greater access to potential business partners.

As a specific type of relationship, cooperation is fundamental in the current business environment because it provides the advantages of being large (economies of scale, economies of expertise, negotiating power, etc.) and being small (capacity to adapt to the market, proximity to customers, etc.) (Kyvik et al., 2013).

Being small and acting like a big firm represents a major evolution in strategic terms. One question here is whether it is better for a particular company to take full control of the value chain (integration) or focus on only a part of this chain and to seek agreements with other upstream and/or downstream firms by forming alliances, integrating networks or developing other forms of cooperation (Tang, 2011; Torkkeli et al., 2012; Freeman et al., 2012).

Johanson and Vahlne (1977) defined psychic distance as the factors that disrupt the flow of information between the company and the market, including factors such as differences in language, culture, political systems, level of education or level of industrial development. According to the aforementioned authors, this is an important concept because internationalisation is based on learning by developing knowledge from experience in foreign markets. To explain internationalisation, it was hypothesised that companies successively enter markets with greater psychological distance.

According to these authors, better knowledge of the country leads to a greater commitment to the market. In turn, knowledge and experience can be gained through a long learning process in conjunction with current business activities. However, research (e.g. Magnani et al., 2018) has shown that the different stages of commitment to foreign markets do not follow a linear path. Internationalisation does not necessarily start in geographically closer countries. On the contrary, distance in its multiple dimensions may actually be attractive if, for example, these dimensions are consistent with the company's strategic objectives.

For companies such as born globals, geographical location and psychic distance are not relevant factors. Furthermore, because many markets are entered simultaneously, these companies can reduce fixed costs, especially when linked to high technology industries and R\&D activities (Gibb and Szałucka, 2012).

Founders of born globals are usually characterised by a high degree of entrepreneurial orientation, pro-activity and international experience. Internationalisation is mainly based on export activities, through cooperation with local companies and a strong use of personal contacts and business networks. Born globals are usually small and medium-sized enterprises with less financial means and resources than traditional multinationals (Gibb and Szałucka, 2012; Amal et al., 2013; Zhou and Wu, 2014).

From another perspective on the influence of age, experience and company size on internationalisation strategies, McDougall et al.'s (1994) research on international new 
ventures challenged the idea that new or small firms could not internationalise (McDougall and Oviatt, 2000; McDougall et al., 1994). They empirically observed that many companies internationalised early, often successfully (McDougall and Oviatt, 1996). There is also empirical evidence that firm size affects internationalisation decisions, namely in terms of entry mode. Smaller firms that lack the resources and experience to venture into foreign markets prefer entry modes with shared solutions (Fletcher and Harris, 2012). For these companies, entering foreign markets in isolation is risky and requires extensive resources. It is therefore not always within the reach of smaller companies. The constraints faced by small firms compel them to look for solutions that minimise risk and commitment (Acs et al., 1997). Thus, small companies tend to use partnerships to internationalise, whereas larger companies prefer entry solutions with a higher degree of commitment (Garcia et al., 2013). Based on these theoretical considerations, we formulate our second hypothesis.

H2: Market characteristics have a significant influence on the strategic approach to internationalisation.

Figure 1 illustrates our theoretical model.

Figure 1 Theoretical model

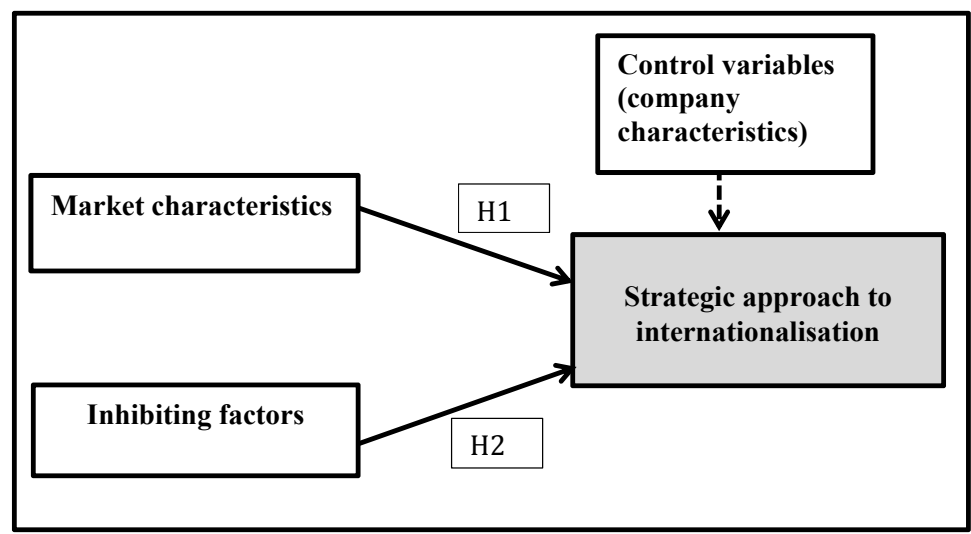

\section{Method}

\subsection{Data and measures}

All variables were chosen based on the literature review. They will be presented in a timely manner. The data were obtained using a questionnaire e-mailed to 8103 exporting companies and/or companies interested in exporting (study population). This list was obtained from the AICEP-Portugal Global Database, which provided the email address of each company's head of internationalisation. We collected 320 valid responses (sample).

\section{Dependent variable}

The strategic approach to internationalisation construct consisted of four items. A 5-point Likert-type scale was used to evaluate the importance $(1=$ not important to $5=$ very important) of each item. The exploratory factor analysis yielded two factors with two 
items each. These factors explained more than $68.0 \%$ of the variability in the data and had eigenvalues greater than 1 . The KMO value was acceptable (0.68) (Table A1). For each factor, the score was calculated as the average of the factor's two constituent items.

\section{Independent variables}

Market characteristics: Six items measured on a 5-point Likert-type scale $(1=$ not important to $5=$ very important) were used to measure the importance of the market characteristics construct. Exploratory factor analysis yielded three components with eigenvalues greater than 1 . These factors explained $73.8 \%$ of the variability in the data. The factors consisted of three, two and one items. The KMO value was acceptable $(\mathrm{KMO}=0.65)($ Table A2). For each of the first two factors, the score was equal to the average of its constituent items. For the last factor, the score corresponded to the score (1 to 5) assigned to its only item.

Inhibiting factors: For the predictor construct of inhibitors, 11 items were used. These items were evaluated on a 5-point Likert-type scale to measure their importance $(1=$ not important to $5=$ very important). Exploratory factor analysis yielded four components that explained $68 \%$ of the variability in the data and had eigenvalues greater than 1 . The $\mathrm{KMO}$ value was good $(\mathrm{KMO}=0.83$; see Table A3). The first dimension had four items, the second had three, and the last two each had two items. For each of the four factors, the score was equal to the average of its items.

\section{Control variables}

The control variables used in the analysis were economic activity, age of the company (in years), time since internationalisation (in years), size of the company (number of employees) and proportion of company turnover resulting from internationalisation (\%).

Table 1 summarises the variables used in the study.

Table 1 Variables used in the analysis

\begin{tabular}{|c|c|}
\hline Variables & Units \\
\hline \multicolumn{2}{|l|}{ Dependent variable } \\
\hline Strategic approach to internationalisation (AS) (2 dimensions)* & Scores from $1-5$ \\
\hline \multicolumn{2}{|l|}{ Independent Variables } \\
\hline Market characteristics (MC) (3 dimensions)** & Scores from $1-5$ \\
\hline Inhibiting factors (IF) (4 dimensions) $)^{* *}$ & Scores from $1-5$ \\
\hline \multicolumn{2}{|l|}{ Control Variables } \\
\hline Manufacturing industry (MAN) & 0 - No; 1 - Yes \\
\hline Non-financial services (SER) & 0 - No; 1 - Yes \\
\hline Age (TAE) & Years \\
\hline Time since internationalisation (TIN) & Years \\
\hline Fewer than 10 workers (MIC) & 0 - No; 1 - Yes \\
\hline 250 or more workers (GRE) & 0 - No; 1 - Yes \\
\hline Less than $10 \%$ turnover from internationalisation $(\mathrm{FAB})$ & 0 - No; 1 - Yes \\
\hline Less than $75 \%$ turnover from internationalisation (FAE) & 0 - No; 1 - Yes \\
\hline
\end{tabular}

Note: $\quad *$ Appendix Table A1; ** Appendix Table A2; *** Appendix Table A3. 


\subsection{Data analysis}

The FEA (Factorial Exploratory Analysis) estimation was based on the principal component method. It was used to determine the number of factors that should be retained. The criteria were that the values should be greater than 1 and that the total variance explained by the factors should be greater than $60 \%$. VARIMAX rotation was used to aid interpretation of the factor solution. The Kaiser-Meyer-Olkin (KMO) criterion was used to evaluate whether the correlation between the variables was acceptable to proceed to the FEA (Hair et al., 2010).

Four multiple linear regression models were estimated: Model 1 consisted of independent variables and control variables; Model 2 consisted of Independent variables and market characteristics; Model 3 consisted of independent variables and inhibiting factors; and Model 4 comprised independent variables, control variables, market characteristics and inhibiting factors) for both dimensions of the strategic approach to internationalisation.

The estimated econometric models were:

$$
\begin{aligned}
1 \quad A E 1_{j}= & \beta_{0}+\beta_{1} T R A_{j}+\beta_{2} S E R_{j}+\beta_{3} T A E_{j}+\beta_{4} T I N_{j} \\
& +\beta_{5} M I C_{j}+\beta_{6} G R E_{j}+\beta_{7} F A B_{j}+\beta_{8} F A E_{J} \\
2 \quad A E 1_{j}= & \beta_{0}+\beta_{1} C M 1_{j}+\beta_{2} C M 2_{J}+\beta_{3} C M 3_{J} \\
3 \quad A E 1_{j}= & \beta_{0}+\beta_{1} F I 1_{j}+\beta_{2} F I 2_{J}+\beta_{3} F I 3_{j}+\beta_{4} F I 4_{J} \\
4 \quad A E 1_{j}= & \beta_{0}+\beta_{1} T R A_{j}+\beta_{2} S E R_{j}+\beta_{3} T A E_{j}+\beta_{4} T I N_{j}+\beta_{5} M I C_{j} \\
& +\beta_{6} G R E_{j}+\beta_{7} F A B_{j}+\beta_{8} F A E_{J}+\beta_{9} C M 1_{j}+\beta_{10} C M 2_{J} \\
& +\beta_{11} C M 3_{J}+\beta_{12} F I 1_{j}+\beta_{13} F I 2_{j}+\beta_{14} F I 3_{j}+\beta_{15} F I 4_{J} \\
5 \quad A E 2_{j}= & \beta_{0}+\beta_{1} T R A_{j}+\beta_{2} S E R_{j}+\beta_{3} T A E_{j}+\beta_{4} T I N_{j} \\
& +\beta_{5} M I C_{j}+\beta_{6} G R E_{j}+\beta_{7} F A B_{j}+\beta_{8} F A E_{J} \\
6 \quad A E 2_{j}= & \beta_{0}+\beta_{1} C M 1_{j}+\beta_{2} C M 2_{J}+\beta_{3} C M 3_{J} \\
7 \quad A E 2_{j}= & \beta_{0}+\beta_{1} F I 1_{j}+\beta_{2} F I 2_{J}+\beta_{3} F I 3_{j}+\beta_{4} F I 4_{J} \\
8 \quad A E 2_{j}= & \beta_{0}+\beta_{1} T R A_{j}+\beta_{2} S E R_{j}+\beta_{3} T A E_{j}+\beta_{4} T I N_{j}+\beta_{5} M I C_{j} \\
& +\beta_{6} G R E_{j}+\beta_{7} F A B_{j}+\beta_{8} F A E_{J}+\beta_{9} C M 1_{j}+\beta_{10} C M 2_{J} \\
& +\beta_{11} C M 3_{J}+\beta_{12} F I 1_{j}+\beta_{13} F I 2_{j}+\beta_{14} F I 3_{j}+\beta_{15} F I 4_{J}
\end{aligned}
$$

We used least squares with robust standard errors to estimate the parameters of the models. This method eliminated possible problems of heteroscedasticity. In all regressions, the possibility of multicollinearity effects was tested using the variance inflation factors (VIF). Values of the VIF should ideally be less than 5 (Hair et al., 2010). 


\section{Results and discussion}

The results of the data analysis of the 320 companies are presented in two sections. The first section discusses the sample characterisation; the second part presents the results of the econometric estimates.

\subsection{Descriptive statistics}

The sample of companies primarily consisted of non-financial service firms $(41.3 \%)$ or manufacturing companies (37.5\%). Companies were created on average $27.8 \pm 22.9$ years ago and were internationalised $15.8 \pm 12.0$ years ago. In terms of number of workers, $28.4 \%$ firms had up to 9 workers, and $13.4 \%$ had 250 or more workers. In $24.4 \%$ of companies, international revenues accounted for less than $10 \%$ of total revenues, and in $23.4 \%$, international revenues accounted for $75 \%$ or more of total revenues (Table 2).

Table 2 Sample characterisation

\begin{tabular}{lccc}
\hline & & $N$ & $\%$ \\
\hline & Manufacturing & 120 & $37.5 \%$ \\
& Construction & 19 & $5.9 \%$ \\
Economic activity & Commerce & 21 & $6.6 \%$ \\
& Non-financial services & 132 & $41.3 \%$ \\
& Others & 28 & $8.8 \%$ \\
\hline Age (years), mean + SD (range) & & $27.8 \pm 22.9(5-183)$ \\
Time since internationalisation (years), mean + SD (range) & $15.8 \pm 12.0(4-98)$ \\
\hline & $=9$ & 91 & $28.4 \%$ \\
Company size & 10 to 49 & 107 & $33.4 \%$ \\
(number of workers) & 50 to 249 & 79 & $24.7 \%$ \\
& 250 to 499 & 17 & $5.3 \%$ \\
& 500 to 1000 & 14 & $4.4 \%$ \\
& $>1000$ & 12 & $3.8 \%$ \\
\hline Revenue from & $>10 \%$ & 78 & $24.4 \%$ \\
internationalisation (\%) & $10 \%$ to $24 \%$ & 69 & $21.6 \%$ \\
& $25 \%$ to $49 \%$ & 56 & $17.5 \%$ \\
& $50 \%$ to $74 \%$ & 42 & $13.1 \%$ \\
& $>=75 \%$ & 75 & $23.4 \%$ \\
\hline
\end{tabular}

Table 3 presents the descriptive statistics and correlation coefficients for the endogenous variables used in the econometric modelling, as well as the VIF. There were no variables with multicollinearity effects (i.e. VIF $<5$ ). 
Table 3 Correlation matrix for the exogenous variables used in the empirical analyses (VIF appears on the diagonal)

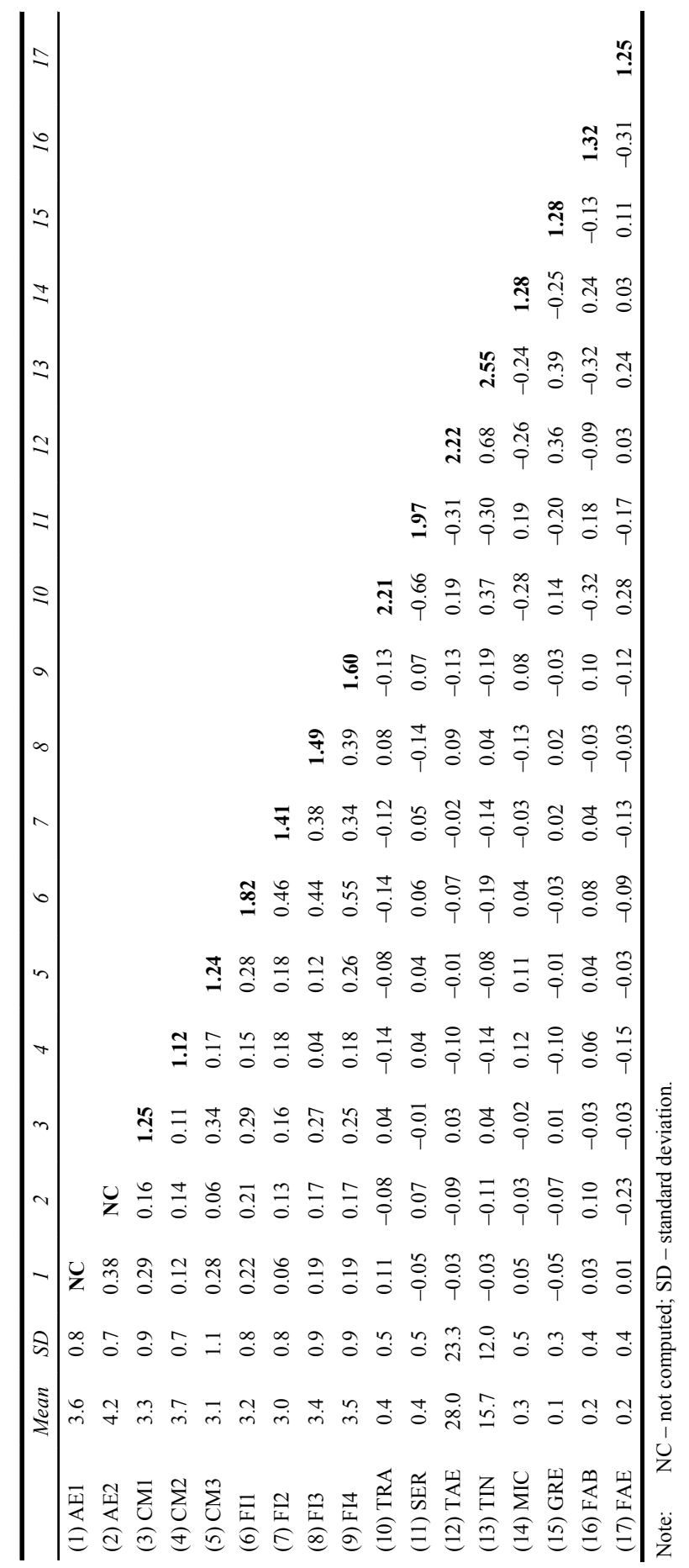




\subsection{Modelling}

Table 4 shows the results for the predicted models of the first dimension of the strategic approach (SA1). This dimension consisted of the items need to explore own resources and need to take advantage of economies of scale. Table 5 displays the results for the predicted models of the second dimension of strategic approach (SA2). This dimensions consisted of the items need to capture new markets/customers and need to reduce/ diversify risks of the internationalisation (SA1 and SA2). All estimates significantly predicted both factors of strategic approach to internationalisation ( $\mathrm{F}$ test: $p<0.05$ ).

In relation to the control variables (company characteristics), manufacturing companies (MAN) had higher levels of statistical significance (Model 1: $\beta=0.30$, $p<0.05$; Model 4: $\beta=0.32, p<0.05$ ) in dimension 1 of the strategic approach to internationalisation (need to exploit own resources and need to take advantage of economies of scale). A different effect was observed for companies with more than $75 \%$ of revenues from international activity (FAE) (Model 5: $\beta=-0.33, p<0.01$; Model 8: $\beta=-0.30, p<0.05$ ) in dimension 2 of strategic approach to internationalisation (need to capture new markets/customers and need to reduce/diversify risks).

Table 4 Regression coefficients (standard error) of the econometric models: dependent variable first dimension of strategic approach to internationalisation (SA1)

\begin{tabular}{|c|c|c|c|c|}
\hline & Model 1 & Model 2 & Model 3 & Model 4 \\
\hline Const. & $3.4(0.15)^{* * *}$ & $2.26(0.26)^{* * *}$ & $2.64(0.23)^{* * *}$ & $1.77(0.35)^{* * *}$ \\
\hline MAN & $0.30(0.14)^{*}$ & & & $0.32(0.13)^{*}$ \\
\hline SER & $0.07(0.13)$ & & & $0.07(0.12)$ \\
\hline TAE & $0.00(0.00)$ & & & $0.00(0.00)$ \\
\hline TIN & $0.00(0.01)$ & & & $0.00(0.01)$ \\
\hline MIC & $0.12(0.11)$ & & & $0.07(0.11)$ \\
\hline GRE & $-0.07(0.15)$ & & & $-0.06(0.14)$ \\
\hline FAB & $0.10(0.12)$ & & & $0.11(0.12)$ \\
\hline FAE & $0.00(0.12)$ & & & $0.02(0.11)$ \\
\hline $\mathrm{MC} 1$ & & $0.17(0.05)^{* * *}$ & & $0.14(0.05)^{* *}$ \\
\hline $\mathrm{MC} 2$ & & $0.08(0.06)$ & & $0.08(0.06)$ \\
\hline MC3 & & $0.13(0.04)^{* *}$ & & $0.13(0.04)^{* *}$ \\
\hline IF 1 & & & $0.17(0.07)^{*}$ & $0.11(0.07)$ \\
\hline IF2 & & & $-0.10(0.07)$ & $-0.10(0.07)$ \\
\hline IF3 & & & $0.12(0.06)^{*}$ & $0.09(0.06)$ \\
\hline IF4 & & & $0.08(0.06)$ & $0.03(0.06)$ \\
\hline$R^{2}$ & $15.4 \%$ & $33.8 \%$ & $28.3 \%$ & $41.9 \%$ \\
\hline$R^{2}$ Adjust. & $7.2 \%$ & $21.4 \%$ & $16.0 \%$ & $37.5 \%$ \\
\hline$F$ & $1.97^{*}$ & $13.12 * * *$ & $6.62 * * *$ & $4.40 * * *$ \\
\hline$N$ & 310 & 310 & 310 & 310 \\
\hline
\end{tabular}

Note: $\quad * p<0.05 ; * * p<0.01 ; p<0.001, F-F$ Statistics. 
Table 5 Regression coefficients (standard error) of the econometric models: dependent variable second dimension of strategic approach to internationalisation (SA2)

\begin{tabular}{|c|c|c|c|c|}
\hline & Model 5 & Model 6 & Model 7 & Model 8 \\
\hline Const. & $4.36(0.12)^{* * *}$ & $3.37(0.23)^{* * *}$ & $3.38(0.2)^{* * *}$ & $3.27(0.32)^{* * *}$ \\
\hline MAN & $-0.02(0.12)$ & & & $0.01(0.12)$ \\
\hline SER & $-0.01(0.11)$ & & & $0.04(0.11)$ \\
\hline TAE & $0.00(0.00)$ & & & $0.00(0.00)$ \\
\hline TIN & $0.00(0.01)$ & & & $0.00(0.01)$ \\
\hline MIC & $-0.09(0.10)$ & & & $-0.10(0.10)$ \\
\hline GRE & $-0.08(0.13)$ & & & $-0.06(0.13)$ \\
\hline FAB & $0.04(0.10)$ & & & $0.08(0.10)$ \\
\hline FAE & $-0.33(0.10)^{* *}$ & & & $-0.30(0.10)^{* *}$ \\
\hline $\mathrm{MC1}$ & & $0.10(0.04)^{*}$ & & $0.07(0.05)$ \\
\hline $\mathrm{MC} 2$ & & $0.14(0.05)^{*}$ & & $0.08(0.06)$ \\
\hline $\mathrm{MC} 3$ & & $0.00(0.04)$ & & $-0.02(0.04)$ \\
\hline IF1 & & & $0.11(0.06)$ & $0.09(0.06)$ \\
\hline IF2 & & & $0.01(0.06)$ & $-0.01(0.06)$ \\
\hline IF3 & & & $0.08(0.05)$ & $0.08(0.05)$ \\
\hline IF4 & & & $0.04(0.05)$ & $0.01(0.05)$ \\
\hline$R^{2}$ & $13.6 \%$ & $20.3 \%$ & $9.1 \%$ & $34.7 \%$ \\
\hline$R^{2}$ Adjust. & $4.6 \%$ & $4.1 \%$ & $14.3 \%$ & $20.6 \%$ \\
\hline$F$ & $2.22 *$ & $4.39 * *$ & $4.70^{* *}$ & $2.60^{* *}$ \\
\hline$N$ & 310 & 310 & 310 & 310 \\
\hline
\end{tabular}

Note: $\quad * p<0.05 ; * * p<0.01 ; p<0.001 ; F-F$ Statistics.

In terms of impact on dimension 1 of the strategic approach to internationalisation (need to exploit own resources and need to take advantage of economies of scale), the first dimension of market characteristics (follow partners, follow clients and follow competitors) (Model 2: $\beta=0.17, p<0.001$; Model 4: $\beta=0.14, p<0.01$ ) and the third dimension of market characteristics (enable access to new technologies or resources) (Model 2: $\beta=0.13, p<0.01$; Model 4: $\beta=0.13, p<0.01$ ) had significant positive influences, as did dimension 1 of inhibiting factors (difficulty managing foreign exchange risk, difficulty recruiting resources in the host country with the required qualifications/skills and difficulty accessing finance) (Model 3: $\beta=0.17, p<0.001$ ) and dimension 3 of inhibiting factors (strong competition in the target market, difficulty hiring resources in the host country with the required qualifications/skills, difficulty accessing finance and difficulty controlling the distribution channels) (Model 3: $\beta=0.12$, $p<0.05$ ). The results therefore support research hypothesis H1: Inhibiting factors have a significant influence on the strategic approach to internationalisation.

Next, we studied the predictive factors of the second dimension of strategic approach to internationalisation (need to capture new markets/customers and need to reduce/diversify risks). Regarding market characteristics, dimension 1 (follow partners, accompany customers and follow competitors) (Model 6: $\beta=0.10, p<0.05$ ) and dimension 2 (weak competition in the new market and good growth prospects in the 
new market) (Model 6: $\beta=0.14 ; p<0,05)$ significantly predicted the strategic approach to internationalisation. The results therefore support research hypothesis H2: Market characteristics have a significant influence on the strategic approach to internationalisation.

The classical economics literature focuses on large companies in analyses of internationalisation (Rowden, 2001; Hollenstein, 2005; Buckley and Ghauri, 1999). Large firms are more capable than SMEs of overcoming market, commercial, political and risk barriers during internationalisation. SMEs experience particular difficulties such as a lack of human, financial, technological and information resources. For Hollenstein (2005), in addition to severe resource constraints, SMEs also face barriers to internationalisation due to country-specific regulations, national laws and market needs.

Technological advances drive internationalisation irrespective of size, segment and location. SMEs access new markets by strategically opting to form cooperative alliances with other companies that provide faster access to these markets (Freeman et al., 2006). Small businesses are typically constrained by a narrower set of capabilities, limited access to market research and an inability to hire specialists who can assist them with internationalisation processes. The risks associated with internationalisation are exacerbated by the fact that the failure of an international venture can have serious negative implications (Knight and Kim, 2009).

Table 6 summarises the support of the hypotheses and their strategic internationalisation approaches.

Table 6 Hypotheses and strategic internationalisation approaches

\begin{tabular}{lcl}
\hline Hypotheses & Supported? & $\begin{array}{l}\text { Strategic Approach of } \\
\text { Internationalisation }\end{array}$ \\
\hline $\begin{array}{l}\text { H1: Inhibiting factors have a } \\
\text { significant influence on the strategic } \\
\text { approach to internationalisation }\end{array}$ & Yes & $\begin{array}{l}\text { Need to exploit own resources and need } \\
\text { to take advantage of economies of scale }\end{array}$ \\
\hline $\begin{array}{l}\text { H2: Market characteristics have a } \\
\text { significant influence on the strategic } \\
\text { approach to internationalisation. }\end{array}$ & Yes & $\begin{array}{l}\text { Need to capture new markets/customers } \\
\text { and need to reduce/diversify risks }\end{array}$ \\
\hline
\end{tabular}

\section{Conclusions}

The objective of this research was to understand if the characteristics of the external market, the characteristics of the company itself and the difficulties associated with internationalisation affect the strategic approach of SMEs during internationalisation.

Our results show that inhibiting factors and market characteristics have a significant influence on the strategic approach to internationalisation which is based on the exploitation of own resources and to take advantage of economies of scale. Furthermore, and in terms of market factors, there is a need to capture new customers.

SMEs may start an internationalisation process because of their existing networks, because of difficulties in accessing venture capital, because of transaction costs or even because of their resources and capabilities. SMEs are truly important for any economy because they contribute to GDP and account for the majority of businesses. When studying SME internationalisation, there are five key areas to consider: networks, venture 
capital, intrinsic characteristics, transaction costs, and resources and capabilities. These areas are widely discussed in the literature, and they explain the internationalisation of SMEs.

The decision of an SME to internationalise should be seen as an institutional change in responses to external pressures in the home country. Under greater institutional pressures, SMEs tend not only to expand further but also to engage in initial international activities more radically. SMEs are highly sensitive to the external environment and respond to the institutional pressures of the home country by moving aggressively to internationalise. Company size, type of ownership, type of activity, availability of external financing, business associations and market share are the remaining variables that may affect the internationalisation process of SMEs.

A key characteristic of economic development is the tertiarisation of economies and their ability to internationalise services. Significant progress in information and communication technology means that many services have become marketable, as reflected by an increase in international trade in services. Competitive pressures on national markets coupled with globalisation have encouraged many companies to cross borders.

However, for many SMEs, national borders still represent a significant barrier to the expansion of their activities and still depend largely or exclusively on their national markets. Current estimates indicate that only one fifth of European SMEs export and only $3 \%$ of SMEs have subsidiaries, branches or joint ventures abroad. Even more worrying is the fact that a substantial proportion of European SMEs do not even ponder about internationalisation, even though they are already exposed to strong international competition even in their own national markets (European Commission, 2008).

Some studies have already shown the direct association between internationalisation and increased profitability of SMEs. Pro-active internationalisation boosts growth, increases competitiveness and supports the long-term viability of enterprises. Despite the advantages, going abroad is still a difficult step for most small businesses. They simply do not have resources or contacts that could inform them about the existence of suitable business opportunities, possible partners or potential openings in external markets.

To overcome this problem, national and regional governments have developed numerous programs to support the internationalisation of SMEs. The first trade promotion body was set up in Finland in 1919 and for many years public support programs have focused exclusively on export promotion through instruments such as export finance credits, trade missions, collective trade exposures, etc (European Commission, 2008). The character and content of these export support measures have evolved with new challenges and new, particularly demanding contexts, but these programs still account for more than $70 \%$ of measures to support the internationalisation of SMEs worldwide.

The Portuguese economy is no exception, as reflected by the international trend of exported goods and services. Faced with the saturation of national markets, companies enter markets with greater potential to sell their goods and services, ensuring propitious conditions for sustained growth and reduced risk. Internationalisation is now much more than just the realm of large companies; it has become part of most SMEs' daily life and a journey that many are already pursuing. Internationalisation is a clear response of Portuguese companies to the saturation of the national market; it is a rational sustainable process based on the emerging opportunities of an increasingly globalised economy. 
Despite this study's contributions to our academic knowledge in this field, we focused on SMEs only from an international strategic approach. In addition to its theoretical implications, this study also helps entrepreneurs understand the factors that promote and hinder the internationalisation process.

This study nonetheless has numerous limitations. Future research should investigate more countries to enrich existing SME internationalisation theory and practices. Although strategic attention was found to have a significant influence in this study, future studies should examine its indirect influence in shaping SME performance. Finally, whilst this study used the strategic choice to analyse approaches to SME internationalisation, it would be of interest to employ other theories and dimensions such as cultural values and institutional theory to extend this research.

\section{Acknowledgement}

This work is supported by FEDER funds from COMPETE 2020 and Portuguese funds PORTUGAL 2020. Project IEcPBI - Interactive Ecosystem for Portuguese Business Internationalization - POCI-01-0145-FEDER-032139.

\section{References}

Acs, Z.J., Morck, R., Shaver, J.M. and Yeung, B. (1997) 'The Internationalization of Small and medium-sized enterprises: a policy perspective', Small Business Economics, Vol. 9, No. 1, pp.7-20.

Ahsan, M. and van Wyk, J. (2018) 'Going paste entry mode: examining foreign operation mode changes at the strategic business unit level', Journal of Managerial Issues, Vol. 30, No. 1, pp.28-46.

Amal, M., Awuah, G.B., Raboch, H. and Anderson, S. (2013) 'Differences and similarities of the internationalization processes of multinational companies from developed and emerging countries', European Business Review, Vol. 25, No. 5, pp.411-428.

Autio, E. (2017) 'Strategic entrepreneurial internationalisation: a normative framework', Strategic Entrepreneurship Journal, Vol. 11, No. 3, pp.211-227.

Barber, J.P. and Darder, F.L. (2004) Direccion de Empresas Internacionales, Pearson, Madrid.

Basle, N., Tominc, P. and Korez-Vide, R. (2018) 'The impact of market knowledge on the internationalisation of small and medium-sized enterprises in Slovenia', European Journal of International Management, Vol. 12, No. 3, pp.334-350.

Baum, J., Calabrese, T. and Silverman, B. (2000) 'Don't go it alone: alliance network composition and startups' performance in Canadian Biotechnology', Strategic Management Journal, Vol. 21, No. 3, pp.267-294.

Benito, G., Petersen, B. and Welch, L. (2009) 'Towards more realistic conceptualisations of foreign operations modes', Journal of Interantional Business Studies, Vol. 40, No. 5, pp.1455-1470.

Blomstermo, A., Eriksson, K., Lindstrand, A. and Sharma, D. (2004) 'The perceived usefulness of network experiential knowledge in the internationalizing firm', Journal of International Management, Vol. 10, No 3, pp.355-373.

Bonardi, J. and Durand, R. (2003) 'Managing network effects in high-tech markets', Academy of Management Executive, Vol. 17, No. 4, pp.40-52.

Braga, A. Marques, C. and Serrasqueiro, Z. (2018) 'Internationalisation strategy of knowledgeintensive business services', Journal of the Knowledge Economy, Vol. 9, pp.359-377. 
Buckley. P. and Ghauri, P. (1999) The Internationalization of the Firms, 2nd ed., International Thomson Business Press, London, New York.

Cuervo-Cazurra, A. and Genc, M. (2008) 'Transforming disadvantages into advantages: developing-country MNEs in the least developed countries', Journal of International Business Studies, Vol. 39, pp.957-979.

Czinkota, M., Ronkainen, I. and Moffett, M. (1999) International Business, 5th ed., The Dryden Press, Orlando.

Dana, L-P. and Wright, R.W. (2004) 'Emerging paradigms on international entrepreneurship', in Dana, L-P. (Ed.): Handbook of Research on International Entrepreneurship, Edward Elgar, Cheltenham, UK, Northampton, MA, USA, pp.3-15.

Dess, G., Lumpkin, G. and Eisner, A. (2008) Strategic Management, McGraw-Hill Irwin, Chicago.

Douglas, S.P. and Craig, C.S. (1995) Global Marketing Strategy, McGraw-Hill, New York.

Dunning, J. (1992) Multinational Enterprises and the Global Economy, Addison-Wesley Publishing Company, Reading, MA.

Dutot, V., Bergeron, F. and Raymond, L. (2014) 'Information Management for the internationalization of SMEs: An exploratory study based on a strategic alignement perspective', International Journal of Information Management, Vol. 34, No. 5, pp.672-681.

Elbana, S. and Child, J. (2007) 'The influence of decision, environmental and firm characteristics on the rationality of strategic decision-making', Journal of Management Studies, Vol. 44, No. 4, pp.561-591.

European Commission (2008) 'Support for the internationalization of SMEs - Selection of good practices', Direç̧ão-Geral da Empresa e da Indústria, Serviço das Publicações Oficiais das Comunidades Europeias. Available online at: https://eur-lex.europa.eu/legal-content/PT/ TXT/?uri=LEGISSUM:n26026

Fernández, Z. and Nieto, M.J. (2005) 'Internationalization Strategy of Small-and medium-sized family business: some influential factors', Family Business Review, Vol. XVIII, No. 1, pp.77-89.

Ferreira, J., Fernandes, C. and Peris-Ortis, M. (2018) 'How agents, resources and capabilities mediate the effect of corporate entrepreneurship on multinational firms' performance', European Journal of International Management, Vol. 12, No. 3, pp.255-277. DOI: 10.1504/EJIM.2018.091369

Fletcher, M. and Harris, S. (2012) 'Knowledge acquisition for the internationalization of the smaller firm: Content and sources', International Business Review, Vol. 21, No. 4, pp.631-647.

Forte, R. and Moreira, A. (2018) 'Financial constraints and small and medium-sized firms' export propensity: evidence from portuguese manufacturing firms', International Journal of the Economics of Business, Vol. 25, No. 2, pp.223-241.

Freeman, S., Edwards, R. and Schroder, B. (2006) 'How smaller born-global firms use networks and alliances to overcome constraints to rapid internationalization', Journal of International Marketing, Vol. 14, No. 3, pp.33-63.

Freeman, S., Hutchings, K. and Chetty, S. (2012) 'Born-globals and culturally proximate markets', Management International Review, Vol. 52, No. 3, pp.425-460.

Garcia, L., Cortés, E. and Ramón, D. (2013) 'Foreign establishment mode: determinants in the caso of Indian multinational Tata Group', Cuadernos de Gestión, Vol. 13, No. 2, pp.89-109.

Gibb, Y. and Szałucka, M. (2012) 'The FDI behaviour of polish companies: equity based entry modes and their impact on performance' European Research Studies Journal, Vol. 15, No. 3, pp.49-80.

Guillén, M. and García-Canal, E. (2009) 'The American model of the multinational firm and the 'new' multinationals from emerging economies', Academy of Management Perspectives, Vol. 23, No. 2, pp.23-35.

Gulati, R. (1998) 'Alliances and networks', Strategic Management Journal, Vol. 19, No. 4, pp.293-317. 
Hair, J., Black, B., Babin, B., Anderson, R. and Tatham, R. (2010) Multivariate Data Analysis, 7 th ed., Pearson Prentice Hall, London, United Kingdom.

Hennebel, V., Simper, R. and Verschelde, M. (2017) 'Is there a prison size dilemma? An empirical analysis of output-specific economies of scale', European Journal of Operational Research, Vol. 262, No. 1, pp.306-321.

Hollenstein, H. (2005) 'Determinants of international activities: are SME's different?' Small Business Economics, Vol. 24, No. 5, pp.431-450. DOI: 10.1007/s11187-005-6455-x

Johanson, J. and Vahlne, J-E. (1977) 'The internationalization process of the firm: a model of knowledge development and increasing foreign market commitments', Journal of International Business Studies, Vol. 8 , pp.23-32.

Johanson, J. and Vahlne, J-E. (2009) 'The Uppsala internationalization process model revisited: from liability of foreignness to liability of outsidership', Journal of International Business Studies, Vol. 40, No. 9, pp.1411-1431.

Johanson, J. and Wiedersheim-Paul, F. (1975) 'The internationalization of the firm: four Swedish cases', Journal of Management Studies, Vol. 12, No. 3, pp.305-322.

Katsikeas, C. and Pierce, N. (1993) 'Long-term export stimuli and firm characteristics in a European LDC', Journal of International Marketing, Vol. 1, No. 3, pp.3-17.

Knight, G.A. and Kim, D. (2009) 'International business competence and the contemporary firm', Journal of International Business Studies, Vol. 40, No. 2, pp.255-273.

Kogut, B. (1989) 'The stability of joint ventures: reciprocity and competitive rivalry', Journal of Industrial Economics, Vol. 38, No. 2, pp.183-198.

Korsakienè, R. and Tvaronavičienè, M. (2012) 'The internationalization of SMEs: an integrative approach', Journal of Business Economics and Management, Vol. 13, No. 2, pp.294-307.

Kotabe, M. and Mudambi, R. (2003) 'Institutions and International Business', Journal of International Management, Vol. 9, No. 3, pp.205-217.

Kraus, S., Niemand, T., Besler, M., Stieg, P. and Martinez-Ciment, C. (2018) 'The influence of leadership styles on the internationalisation of 'born-global' firms and traditionally global-expanding firms', European Journal of International Management, Vol. 12, Nos. 5/6, pp.554-575. DOI: 10.1504/EJIM.2018.094457

Kyvik, O., Saris, W., Bonet, E. and Felício, J.A. (2013) 'The internationalization of small firms: the relationship between the global mindset and firms' internationalization behavior', Journal of International Entrepreneurship, Vol. 11, No. 2, pp.172-195.

Lam, L.W. and White, L.P. (1999) 'An adaptive choice model of the internationalization process', International Journal of Organizational Analysis, Vol. 7, No. 2, pp.105-134.

Lambe, C., Spekman, R. and Hunt, S. (2002) 'Alliance competence, resources, and alliance success: conceptualization, measurement, and initial test', Journal of the Academy of Marketing Science, Vol. 30, No. 2, pp.141-158.

Lockyer, K. (2013) A Radical Plan To Reform The Prison Estate Policy Exchange, London, UK.

Luo, X., Zhou, L. and Liu, S. (2005) 'Entrepreneurial firms in the context of China's transition economy: an integrative framework and empirical examination', Journal of Business Research, Vol. 58, No. 3, pp.277-284.

Magnani, G., Zucchella, A. and Floriani, D.E. (2018) 'The logic behind foreign market selection: objective distance dimensions vs. strategic objectives and psychic distance', International Business Review, Vol. 27, No. 1, pp.1-20.

Malhotra, S., Sivakumar, K. and Zhu, P. (2009) 'Distance factors and target market selection: the moderating effect of market potential', International Marketing Review, Vol. 26, No. 6, pp.651-673.

Mathews, J. (2006) 'Dragon multinationals: new players in 21st century globalization', Asia Pacific Journal of Management, Vol. 23, No. 1, pp.5-27.

McDougall, P. and Oviatt, B.M. (2000) 'International entrepreneurship: the intersection of two research paths', Academy of Management Journal, Vol. 43, No. 5, pp.902-906. 
McDougall, P. and Oviatt, B.M. (1996) 'New venture internationalization, strategic change, and performance: A follow-up study', Journal of Business Venturing, Vol. 11, No. 1, pp.23-40.

McDougall, P., Shane, S. and Oviatt, B.M. (1994) 'Explaining the formation of international new ventures: the limits of theories from international business research', Journal of Business Venturing, Vol. 9, No. 6, pp.469-487.

Moghaddam, K., Sethi, D., Weber, T. and Wu, J. (2014) 'The smirk of emerging markets firms: a modification of the Dunning's typology of internationalization motivations', Journal of International Management, Vol. 20, pp.359-374.

Nigh, D. (1985) 'The effect of political events on united states direct foreign investment: a pooled time-series cross-sectional analysis', Journal of International Business Studies, Vol. 16, No. 1, pp.1-17.

Parkhe, A. (2003) 'Institutional environments, institutional change and international alliances', Journal of International Management, Vol. 9, No. 3, pp.305-316.

Pedersen, T., Petersen, B. and Benito, G. (2002) 'Change of foreign operation method: impetus and switching costs', International Business Review, Vol. 11, pp.325-345.

Pellegrino, J. and McNaughton, R. (2015) 'The co-evolution of learning and internationalization strategy in international new ventures', Management International Review, Vol. 55, No. 4, pp.457-483.

Peng, M. (2009). Global Strategic Management, 2nd ed., South-Western Cengage Learning.

Puck, J., Holtbrugge, D. and Mohr, A. (2009) 'Beyond entry mode choice: explaining the conversion of joint ventures into wholly owned subsidiaries in the People's Republic of China', Journal of International Business Studies, Vol. 40, pp.388-404.

Raoul, M., Murro, P. and Zhu, S. (2015) 'Family firms, corporate governance and export', Economica, Vol. 82, pp.1177-1216.

Raposo, M., Ferreira, J. and Fernandes, C. (2014) 'Local and cross-border SME cooperation: effects on innovation and performance', Revista Europea de Dirección y Economia de la Empresa, Vol. 23, No. 4, pp.157-165.

Rowden, R. (2001) 'Research note: how a small business enters the international market', Thunderbird International Business Review, Vol. 4, No. 2, pp.257-268. DOI: 10.1002/tie.5

Rui, H. and Yip, G. (2008) 'Foreign acquisitions by Chinese firms: a strategic intent perspective', Journal of World Business, Vol. 43, No. 2, pp.213-226.

Sapienza, H., Autio, E., George, G. and Zahra, S. (2006) 'A capabilities perspective on the effects of early internationalization on firm survival and growth', Academy of Management Review, Vol. 31, No. 4, pp.914-933.

Sethi, D., Guisinger, S., Phelan, S. and Berg, D. (2003) 'Trends in foreign direct investment flows: a theoretical and empirical analysis', Journal of International Business Studies, Vol. 34, No. 4, pp.315-326.

Tang, Y.K. (2011) 'The Influence of networking on the internationalization of SMEs: evidence from internationalized Chinese firms', International Small Business Journal, Vol. 29, No. 4, pp.374-398.

Torkkeli, L., Puumalainen, K., Saarenketo, S. and Kuivalainen, O. (2012) 'The effect of network competence and environmental hostility on the internationalization of SMEs', Journal of International Entrepreneurship, Vol. 10, No. 1, pp.25-49.

Van Tulder, R. (2015) 'Getting all motives right: a holistic approach to internationalization motives of companies', The Multinational Business Review, Vol. 23, No. 1, pp.36-56.

Yamin, M. and Sinkovics, R.R. (2006) 'Online internationalisation, psychic distance reduction and the virtuality trap', International Business Review, Vol. 15, No. 4, pp.339-360.

Zhou, L. and Wu, A. (2014) 'Earliness of internationalization and performance outcomes: Exploring the moderating effects of venture age and international commitment', Journal of World Business, Vol. 49, No. 1, pp.132-142. 


\section{Appendix A}

Table A1 Strategic approach to internationalisation: descriptive statistics, factor loadings, communalities, eigenvalues and explained variance (\%)

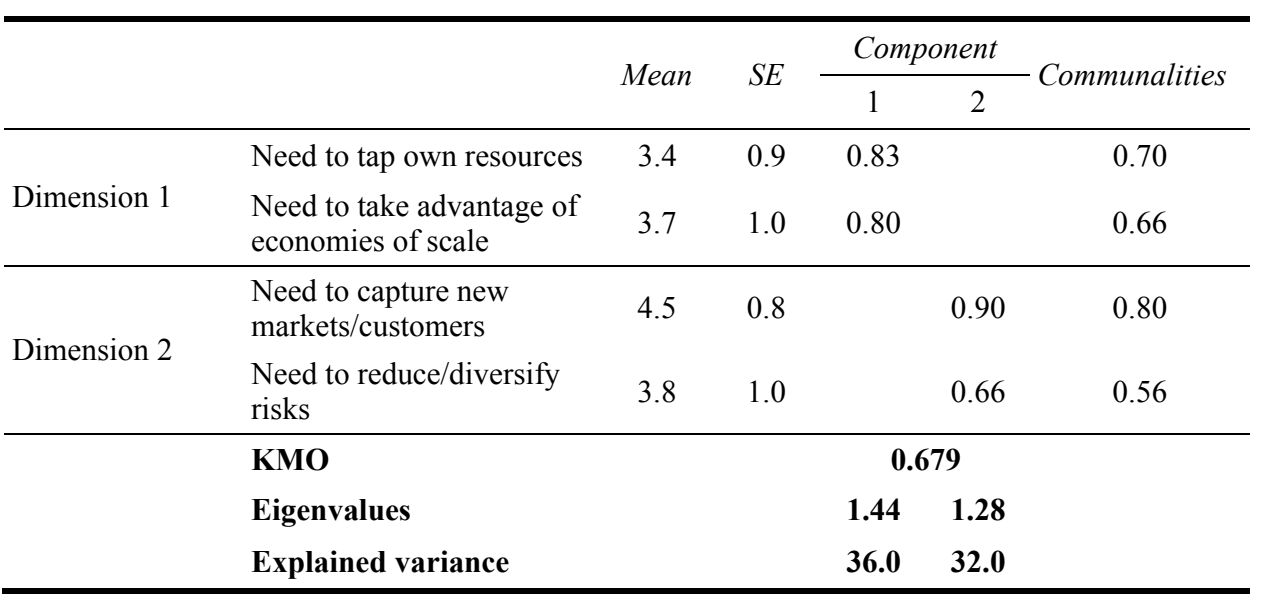

Table A2 Market characteristics: descriptive statistics, factor loadings, communalities, eigenvalues and explained variance (\%)

\begin{tabular}{|c|c|c|c|c|c|c|c|}
\hline & & \multirow{2}{*}{ Mean } & \multirow{2}{*}{$S E$} & \multicolumn{3}{|c|}{ Component } & \multirow{2}{*}{ Communalities } \\
\hline & & & & 1 & 2 & 3 & \\
\hline \multirow{3}{*}{ Dimension 1} & Follow partners & 3.3 & 1.1 & 0.87 & & & 0.77 \\
\hline & Accompany customers & 3.7 & 1.1 & 0.81 & & & 0.67 \\
\hline & Follow competitors & 2.9 & 1.2 & 0.66 & & & 0.65 \\
\hline \multirow{2}{*}{ Dimension 2} & $\begin{array}{l}\text { Weak competition in the } \\
\text { new market }\end{array}$ & 3.1 & 1.1 & & 0.81 & & 0.73 \\
\hline & $\begin{array}{l}\text { Good growth prospects } \\
\text { in the new market }\end{array}$ & 4.3 & 0.7 & & 0.79 & & 0.72 \\
\hline \multirow[t]{4}{*}{ Dimension 3} & $\begin{array}{l}\text { Access to new } \\
\text { technology or resources }\end{array}$ & 3.1 & 1.1 & & & 0.91 & 0.88 \\
\hline & KMO & & & & 0.652 & & \\
\hline & Eigenvalues & & & 1.97 & 1.33 & 1.12 & \\
\hline & Explained variance & & & 32.9 & 22.2 & 18.6 & \\
\hline
\end{tabular}


Table A3 Inhibitory factors: descriptive statistics, factor loadings, communalities, eigenvalues and explained variance (\%)

\begin{tabular}{|c|c|c|c|c|c|c|c|c|}
\hline & & \multirow{2}{*}{ Mean } & \multirow{2}{*}{$S E$} & \multicolumn{4}{|c|}{ Components } & \multirow{2}{*}{ Communalities } \\
\hline & & & & 1 & 2 & 3 & 4 & \\
\hline \multirow{4}{*}{ Dimension 1} & $\begin{array}{l}\text { difficulty managing } \\
\text { foreign exchange risk }\end{array}$ & 3.0 & 1.1 & 0.75 & & & & 0.71 \\
\hline & $\begin{array}{l}\text { difficulty developing } \\
\text { the structure of the } \\
\text { company abroad }\end{array}$ & 3.3 & 1.1 & 0.73 & & & & 0.65 \\
\hline & $\begin{array}{l}\text { difficulty hiring } \\
\text { resources in the host } \\
\text { country with the } \\
\text { required } \\
\text { qualifications/ skills }\end{array}$ & 3.2 & 1.1 & 0.65 & & & & 0.74 \\
\hline & $\begin{array}{l}\text { difficulty accessing } \\
\text { finance }\end{array}$ & 3.3 & 1.1 & 0.50 & & & & 0.61 \\
\hline \multirow[b]{3}{*}{ Dimension 2} & cultural differences & 3.1 & 0.9 & & 0.84 & & & 0.73 \\
\hline & language differences & 2.8 & 1.0 & & 0.78 & & & 0.70 \\
\hline & $\begin{array}{l}\text { insufficient staff in } \\
\text { the company with } \\
\text { international } \\
\text { experience }\end{array}$ & 3.3 & 1.0 & & 0.66 & & & 0.59 \\
\hline \multirow{2}{*}{ Dimension 3} & $\begin{array}{l}\text { competition in the } \\
\text { target market }\end{array}$ & 3.5 & 0.9 & & & 0.81 & & 0.68 \\
\hline & $\begin{array}{l}\text { difficulty controlling } \\
\text { distribution channels }\end{array}$ & 3.3 & 1.1 & & & 0.60 & & 0.52 \\
\hline \multirow{5}{*}{ Dimension 4} & $\begin{array}{l}\text { legal issues in the } \\
\text { host country }\end{array}$ & 3.6 & 1.1 & & & & 0.85 & 0.81 \\
\hline & $\begin{array}{l}\text { inadequate } \\
\text { support/incentives for } \\
\text { internationalisation }\end{array}$ & 3.4 & 1.1 & & & & 0.69 & 0.73 \\
\hline & КМO & \multicolumn{7}{|c|}{0.832} \\
\hline & Eigenvalues & & & 2.11 & 2.07 & 1.71 & 1.59 & \\
\hline & Explained variance & & & 19.2 & 18.9 & 15.5 & 14.5 & \\
\hline
\end{tabular}

